has passed to the buyer, the latter may be insolvent-one of the contingencies which retention of the security interest was designed to cover. Allowance of an action by the shipper against the carrier should thus remain.

Perhaps a desirable rule governing the carrier's liability would be: where a carrier of goods on an order-notify bill of lading fails to notify the consignor of any non-acceptance of the goods by the notify party, the carrier will be absolutely liable for subsequent loss or damage; provided, however, that the carrier may be relieved of his duty of notification, where the seller has or should have knowledge eliminating the necessity of notification. Such "knowledge" could be actual notice received by the consignor from his bank, or directly from the notify party. A long delay prior to loss (such as occurred in the principal case), during which time the consignor should be expected to exercise reasonable care in inquiring as to the disposition of his goods, should also constitute "knowledge."

Such a rule seems justified by several considerations. In the first place, no great additional burden is placed on the carrier, since custom already required that notice be given. ${ }^{36}$ Moreover, the great difficulty involved in proving damages $^{37}$ should prevent a deluge of groundless suits. It may also be hoped that a rule of absolute liability would not only preserve the duty of care of the shipper, but would re-emphasize the responsibility of the carrier in this situation.

\title{
THE LIMITS OF CONSTITUTIONAL INQUIRY ON HABEAS CORPUS IN INTERSTATE RENDITION
}

The writ of habeas corpus, historically the guardian of human liberty in the Anglo-American world, ${ }^{1}$ is an important procedural device in interstate rendition $^{2}$ proceedings. The traditional conception of the function of the writ in such

${ }^{36}$ See note 11 supra. Interviews with freight agents reveal that the railroad is acutely aware of the necessity of giving notice in all cases where an order-notify bill is involved. It is only where an agent "slips up" that notice is not given, and in the case of perishables it is customarily given by phone or telegraph. 1952).

${ }^{37}$ E.g., Tri-State Produce Co. v. Chicago, B. \& Q. R. Co., 104 F. Supp. 452 (N.D. Iowa,

${ }^{I}$ See Ex parte Yerger, 8 Wall. (U.S.) 85 (1868). "The Great Writ (habeas corpus ad subiiciendum) always serves the function of precipitating a judicial inquiry into a claim of illegality in the petitioner's detention for the purpose of commanding his release, or other appropriate disposition, if he is found to be illegally detained. The underlying premise is, of course, that only law can justify detention, the specific contribution of the English struggle with royal prerogative in which the writ played an historic part." Hart \& Wechsler, The Federal Courts and the Federal System, 1238 (1953).

2 Rendition is normally defined as the surrender by one state of persons found within its jurisdiction to another state in whose territory they are alleged to have committed, or to have been convicted of, crime, so that they might be dealt with according to the penal laws of the latter state. Kopelman, Extradition and Rendition, 14 B. U. L. Rev. 591, 624 (1934). In strict correctness the word "extradition" applies only to the international process of surrendering fugitives, and "interstate rendition" to the comparable process between the states of the 
proceedings has been exceedingly narrow; the expanded scope of the writ in other contexts ${ }^{3}$ has led to strong pressure to extend the permissible area of inquiry when a person detained under an extradition warrant invokes the writ in protection of his constitutional rights. This pressure has evoked judicial response in several characteristic types of cases: a fugitive claims that his extradition to the demanding state will subject him to possible or probable lynching or that prejudice on account of race or other reasons makes a fair and impartial .trial in the demanding state impossible; an escaped prisoner detained for extradition claims that the demanding state has subjected him in the past to cruel and inhuman punishment in violation of his constitutional rights, or that his indictment or his conviction in the demanding state is itself void because of constitutional defects; a fugitive detained for extradition claims that he is not charged with crime because the crime alleged is itself unconstitutional. Broadly put, the question presented by these cases is whether the courts of the asylum state have jurisdiction on habeas corpus to inquire into the fugitive's constitutional claim.

The law, abstractly conceived, requires that the fugitive from justice, charged with a crime by the demanding state, be delivered up by the authorities of the asylum state, and that the constitutional questions raised by the person involved be considered in a forum located in the demanding state. The almost automatic operation of the rendition process is essential to the control of crime and the furtherance of criminal justice; yet the rights of the individual must be carefully preserved: the individual is entitled to security of residence in the state of his choosing, he should be protected from unwarranted prosecution, and his life and liberty must not be taken from him without due process of law. Faced in the extreme case with an appealing constitutional claim asserted on behalf of the often-beleaguered fugitive, some courts have strained against, and occasionally even ignored, the traditional bounds of the habeas corpus hearing in extradition cases.

United States. Moore, Extradition and Interstate Rendition (1891); Scott, Interstate Rendition (1917); Kopelman, supra. However, there is no consistent adherence to this usage in the cases, and the use of "extradition" for either process has been furthered by the Uniform Criminal Extradition Act, 9 U.L.A. 169 (1951), hereafter to be cited as U.C.E.A. Herein the words "rendition" and "extradition" are used interchangeably.

3 Traditionally, hearings on the writ of habeas corpus inquired into the jurisdiction of the detaining authority. The theory that jurisdiction may be lost during the trial expanded the scope of inquiry: "A court's jurisdiction at the beginning of trial may be lost in the course of the proceedings' due to failure to complete the court ... by providing counsel.... The judgement of conviction pronounced by a court without jurisdiction is void. . .." Johnson v. Zerbst, 304 U.S. 458,468 (1938). It now appears that the writ is an appropriate remedy in "those exceptional cases where the conviction [in a state court] has been in disregard of the constitutional rights of the accused, and where the writ is the only effective means of preserving his rights." Waley v. Johnston, 316 U.S. 101, 105 (1942). The use of habeas corpus to correct errors of due process during trial is illustrated by House v. Mayo, 324 U.S. 42 (1945), and Johnson v. Zerbst, supra. Consult The Freedom Writ-The Expanding Use of Federal Habeas Corpus, 61 Harv. L. Rev. 657 (1948). 
Criminal rendition is based on the Constitution, ${ }^{4}$ implemented by federal statute, ${ }^{5}$ and supplemented by state law. ${ }^{6}$ The mechanics of the rendition procedure are simple: a fugitive from justice found in another state (the asylum state) must be turned over to the governor of the demanding state upon presentation of an indictment or affdavit charging such fugitive with the commission of a crime." "Such is the command of the supreme law of the land, which may not be disregarded by any State." "Although the governor of the asylum state is under a duty to return the fugitive, there is no way to compel him to do so. ${ }^{9}$

A habeas corpus hearing cannot arise until the governor of the asylum state issues his warrant and the fugitive is apprehended. At that time, however, the fugitive may test the legality of his arrest and detention by seeking release through the writ of habeas corpus. ${ }^{10}$ The accused should be released, according to the traditional conception of habeas corpus in rendition cases, if he can prove either: (1) that the papers under which he is held are not in proper form;" ${ }^{11}$ or (2) that he is not the person who is charged in the requisition;12 or (3) that he was not present in the demanding state when the alleged crime was committed; ${ }^{13}$

'U.S. Const. Art. 4, \& 2, cl. 2: "A Person charged in any State with Treason, Felony, or other Crime, who shall flee from Justice, and be found in another State, shall on Demand of the executive Authority of the State from which he fled, be delivered up, to be removed to the State having Jurisdiction of the Crime."

562 Stat. 822 (1948), 18 U.S.C.A. $\$ 3182$ (1951). The wording remains fundamentally the same as the statute originally enacted in 1793 to implement the constitutional provision, which was not believed to be self-executing. 1 Stat. 302 (1793).

'E.g., the Illinois Fugitives from Justice Act $\$ 2$, Ill. Rev. Stat. (1953) c. 60, $\S 2$. The Uniform Criminal Extradition Act, prepared in 1926 and revised in 1936, has been adopted by forty states. See 9 U.L.A. 40 (Supp., 1953). The federal statute enunciates the method by which the constitutional provision is to becarried out; since it is not all-inclusive, the various states have enacted alternative procedures, chief among them being the U.C.E.A.

${ }^{7}$ Commonwealth of Kentucky v. Dennison, 24 How. (U.S.) 66 (1860).

3 Appleyard v. Massachusetts, 203 U.S. 222, 227 (1906).

- Commonwealth of Kentucky v. Dennison, 24 How. (U.S.) 66 (1860).

${ }^{10}$ Neither the Constitution nor the federal statute provides for habeas corpus when a person is detained for extradition, but the writ has been available in extradition cases from a very early date. Robb v. Connolly, 111 U.S. 624 (1884). The U.C.E.A. \& 10 explicitly provides that the accused is entitled to a habeas corpus hearing in the asylum state.

11 Ex parte Hart, 63 Fed. 249 (C.A. 4th, 1894); Ex parte Spears, 88 Cal. 640, 26 Pac. 608 (1891); In re Waterman, 29 Nev. 288, 89 Pac. 291 (1907). This inquiry into the correctness of the form of the requisition papers and warrant does not extend to the indictment-the technical sufficiency of the indictment as a criminal pleading will not be inquired into. Pierce v. Creecy, 210 U.S. 387 (1908); Nevada v. Stacher, 346 U.S. 906 (1953).

22 Barnes v. Nelson, 23 S.D. 181, 121 N.W. 89 (1909).

12 This is the question whether the person is a "fugitive from justice." If the accused can show that he was not present in the demanding state at the time the alleged crime was committed, he should be discharged. People ex rel. Sherman v. Barr, 131 N.Y. Misc. 915, 229 N.Y. Supp. 268 (S. Ct., 1928). The accused need not have consciously fled to avoid prosecution in 
or (4) that he is not substantially charged with a crime under the laws of the demanding state. ${ }^{14}$ Of these four specific questions three are questions of fact and the fourth a question of law. ${ }^{15} \mathrm{It}$ is under the guise of substantial charge of crime that constitutional claims have been most often asserted.

Attempts by the accused to introduce evidence involving his innocence or guilt or to assert a defense to the crime charged have been given short shrift by the courts. "[T]he constitutionally required surrender is not to be interfered with by the summary process of habeas corpus upon speculations as to what ought to be the result of a trial in the place where the Constitution provides for its taking place."16 $\mathrm{A}$ person is charged with a crime when a state makes a formal accusation against him, ${ }^{17}$ and the technical sufficiency of the indictment or affdavit may not be inquired into on habeas corpus. ${ }^{18}$ The accused is not permitted to raise as a defense the fact that he was illegally abducted from the asylum state and brought into the demanding state..$^{19}$ The accused must be extradited even though he is insane, and therefore cannot be convicted of any crime. ${ }^{20}$ And even a showing that the statute of limitations of the demanding state bars a prosecution for the crime charged will not prevent his rendition. ${ }^{21}$

The motives of the demanding state in requesting extradition have been investigated by some courts, ${ }^{22}$ constituting the one occasional exception to the

order to be a fugitive from justice. Appleyard v. Massachusetts, 203 U.S. 222 (1906). Actual presence in the demanding state is required, Hyatt v. Corkran, 188 U.S. 691 (1903), except under Section 6 of the U.C.E.A., a change which is of particular importance in abandonment and non-support cases.

14 Ex parte Hart, 59 Fed. 894 (C.C. Md., 1894); Ex parte Reggel, 114 U.S. 642 (1885); Commonwealth v. Hare, $36 \mathrm{~Pa}$. Super. 125 (1908).

${ }^{15}$ See Roberts v. Reilly, 116 U.S. 80,95 (1885).

${ }^{16}$ Drew v. Thaw, 235 U.S. 432, 440 (1914).

17 '[T] any proceeding which a State might see fit to adopt by which a formal accusation was made against an alleged criminal." In the Matter of Strauss, 197 U.S. 324, 331 (1905).

18 "These are matters for the trial court of the demanding state, and are not to be inquired of on this writ." Munsey v. Clough, 196 U.S. 364, 373 (1905); Pierce v. Creecy, 210 U.S. 387, 405 (1908). See cases cited note 11 supra.

${ }^{19}$ Pettibone v. Nichols, 203 U.S. 192 (1906) (jurisdiction of demanding state attaches when the accused is brought into the state, however illegal the abduction may have been).

${ }^{20}$ Drew v. Thaw, 235 U.S. 432 (1914) (defense of insanity will not be inquired into in asylum state).

${ }^{21}$ Biddinger v. Commissioner of Police, 245 U.S. 128 (1917) (defense of statute of limitations cannot be inquired into in asylum state).

22 Ex parte Slauson, 73 Fed. 666 (C.C. Va., 1896); Ex parte Maddox, 55 Okla. Cr. 114, 25 P. 2d 1111 (1933); Ex parte Cassel, 85 Okla. Cr. 4, 184 P. 2d 467 (1947); Ex parte Patrick, 86 Okla. Cr. 61,189 P. 2d 420 (1948). The governor of the asylum state may, at his discretion, refuse to grant a warrant for extradition if he decides the motive for extradition is improper. When it is suspected that extradition is sought to aid the service of civil process (e.g., the collection of a debt) an extradition warrant may be denied. See Barranger v. Baum, $103 \mathrm{Ga}$. 465 , 30 S.E. 524 (1898); Work v. Corrington, 34 Ohio St. 64 (1877); State ex rel. Nisbett v. Toole, 69 Minn. 104, 72 N.W. 53 (1897). 
rule that the courts of the asylum state could not inquire into anything involving the innocence or guilt of the accused. However, the vast majority of the courts have held that the motives of the prosecutor or of either of the governors are not open to judicial investigation, ${ }^{23}$ and at least one state formerly allowing this inquiry has reached the contrary result under the Uniform Criminal Extradition Act. ${ }^{24}$

\section{II}

Cases in which a constitutional claim is asserted by the fugitive detained for extradition fall into three broad classes: (1) where the fugitive claims a prospective deprivation of constitutional rights, (2) where he claims a past deprivation of constitutional rights, ${ }^{25}$ and (3) where he claims that the crime alleged is itself unconstitutional.

A number of cases have explicitly dealt with a claim asserted by a detained fugitive that he will in the future be denied the protection of constitutional due process if returned to the demanding state, ${ }^{26}$ but in only one of them, Commonwealth ex rel. Maltox v. Superintendent of Prison, ${ }^{27}$ was the fugitive released. In the earliest, Marbles v. Creecy, ${ }^{28}$ a Negro fugitive alleged that he would be in danger of being lynched if returned. The Supreme Court held that such an allegation by a fugitive could not prevent his extradition. The Third Circuit later held in United States ex rel. Brown v. Cooke ${ }^{29}$ that a federal court in the asylum state could not consider whether or not the fugitive would receive a fair trial in the demanding state, since the matters open to judicial inquiry in the habeas

23 Pettibone v. Nichols, 203 U.S. 192 (1906); Worth v. Wheatley, 183 Ind. 598, 108 N.E. 958 (1915); Commonwealth ex rel. Flower v. Superintendent of Prison, 220 Pa. 401, 69 Atl. 916 (1908). A statute providing that habeas corpus be issued where "the requisition is not made in good faith but is for some ulterior purpose other than the punishment of crime" has been held unconstitutional. People ex rel. Carr v. Murray, 357 III. 326, 192 N.E. 198 (1934).

24 Ex parte Scott, 91 Okla. Cr. 345, 219 P. 2d 249 (1950). U.C.E.A. $\$ 20$ explicitly provides that there be no inquiry in the asylum state into the guilt or innocence of the accused. This has been uniformly interpreted as forbidding any judicial investigation of motives. Moreaux v. Ferrin, 98 Utah 450, 100 P. 2d 560 (1940).

${ }^{26}$ The problem is often complicated by the fact that in a number of the cases the fugitive involved has claimed both a past and a prospective deprivation of constitutional rights. In these situations the courts have rarely dealt with both of the claims, but have decided the case on the basis of one or blended the two together without distinguishing between them.

${ }^{26}$ Marbles v. Creecy, 215 U.S. 63 (1909); United States ex rel. Brown v. Cooke, 209 Fed 607 (C.A. 3d, 1913), appeal dismissed for lack of jurisdiction, 238 U.S. 613 (1914); Ople v* Weinbrenner, 285 Mo. 365, 226 S.W. 256 (1920), cert. denied, 256 U.S. 695 (1921); Ex parte Ray, 215 Mich. 156, 183 N.W. 774 (1921); In re Paramore, 95 N.J. Eq. 386, 123 Atl. 246 (Ch., 1924), aff'd, 96 N.J. Eq. 397, 125 Atl. 926 (Err. \& App., 1924); Commonwealth ex rel. Mattox v. Superintendent of Prison, $152 \mathrm{~Pa}$. Super. 167, 31 A. 2d 576 (1943); and Commonwealth ex rel. Mills v. Baldi, 166 Pa. Super. 321, 70 A. $2 d 439$ (1950), cert. denied, 339 U.S. 986 (1950).

${ }^{27} 152$ Pa. Super. 167, 31 A. 2d 576 (1943).

29215 U.S. 63 (1909).

${ }^{29} 209$ Fed. 607 (C.A. 3d, 1913). 
corpus proceeding are strictly limited to the legality of the detention by the asylum state. But in the Mattox case the Pennsylvania court concluded that "where there is sufficient competent evidence to sustain a charge that the accused relator will be unable to have a fair trial and will be in grave danger of being lynched if returned ... the judge hearing the writ of habeas corpus may refuse to give him over into the custody of [the demanding state's] representatives." 30 The facts of the Mattox case were extreme: the accused was a youth -of sixteen at the time of the alleged crime and there was plentiful evidence of mob feeling running so high that lynching was not improbable. ${ }^{31}$ The case does not fit into the customary categories of questions inquired into in rendition cases. Certainly the prospective denial of constitutional rights has nothing to do with the legality of the accused's detention by the asylum state. The rationale of the Maltox case rests on a different ground entirely: if Mattox were lynched upon his return to the demanding state the damage would be irreparable - no other remedy would then be available to him.

A much larger number of cases, more recent in point of time, have been concerned with an alleged past deprivation of the fugitive's constitutional rights. ${ }^{32}$ In Hale v. Crawford ${ }^{33}$ an agreed set of facts showed that the indictment against the accused was returned by a grand jury selected without Negroes, depriving the accused of the equal protection of the laws. The First Circuit held that this

${ }^{30}$ Commonwealth ex rel. Mattox v. Superintendent of Prison, 152 Pa. Super. 167, 173, 31 A. 2d 576, 578 (1943).

g1 The Pennsylvania court, understandably impressed by the tenor of the evidence introduced by the petitioner, felt that "an ounce of prevention . . . is worth a pound of cure." Ibid., at 177 and 580. The decision relied heavily on a phrase in the U.C.E.A. \& 10, in force in Pennsylvania, that a judge "may inquire into the facts of the case," and on negative inferences drawn from statements in Marbles v. Creecy, 215 U.S. 63, 69-70 (1909), and Commonwealth ex rel. Flower v. Superintendent of Prison, $220 \mathrm{~Pa}$. 401, 411, 69 Atl. 916, 919 (1908). For a discussion of the Mattox case, see 53 Yale L. J. 359 (1944); 47 Col. L. Rev. 470 (1947); 17 Temp. I. Q. 469 (1943); Alexander, The Thomas Mattox Extradition Case, 2 Nat. Bar J. 1 (1944).

32 The cases can be broken down into two categories:

(1) Petitioner, a person who has fed prior to his trial, claims that the indictment returned against him in the demanding state is void since the grand jury was selected solely of whites, in violation of the Fourteenth Amendment. People ex rel. Whitfield v. Enright, 117 N.Y. Misc. 448,191 N.Y. Supp. 491 (S. Ct., 1921); Hale v. Crawford, 65 F. 2d 739 (C.A. 1st, 1933); Wilson v. Turner, $168 \mathrm{Kan} .1,208$ P. 2d 846 (1949).

(2) Petitioner, an escaped prisoner, claims that his conviction was obtained without due process and/or that he has been subject to cruel and unusual punishment while confined in the demanding state. Powell v. Meyer, 134 N.J.L. 169, 46 A. 2d 671 (S. Ct., 1946); In re Cotton, 24 N.J. Misc. 267, 47 A. 2d 830 (S. Ct., 1946); In re Colier, 140 N.J. Eq. 469, 55 A. 2d 29 (Err. \& App., 1947); Johnson v. Dye, 175 F. 2d 250 (C.A. 3d, 1949); Harper v. Wall, 85 F. Supp. 783 (D. N.J., 1949); Ex parte Marshall, 85 F. Supp. 771 (D. N.J., 1949); Ex parte Quilliam, 89 N.E. 2d 493 (Court of Appeals Ohio, 1949), appeal dismissed, 152 Ohio St. 368, 89 N.E. 2d 494 (1949); United States ex rel. Jackson v. Ruthazer, 181 F. 2d 588 (C.A. 2d, 1950); Johnson v. Matthews, 182 F. 2 d 677 (App. D.C., 1950); Davis v. O'Connell, 185 F. 2d 513 (C.A. 8th, 1950); Ross v. Middlebrooks, 188 F. 2d 308 (C.A. 9th, 1951); Sweeney v. Woodall, 344 U.S. 86 (1952).

s3 65 F. $2 d 739$ (C.A. 1st, 1933). 
evidence could not be considered by a federal court in the asylum state, but presented a question solely for the courts of the demanding state. ${ }^{34}$ The rationale underlying the petitioner's claim was that there was no substantial charge of crime, since the indictment by which the demanding state alleged a crime against him and by reason of which he was held was void as unconstitutionally obtained. ${ }^{35}$

Some sixteen years later the first of the "chain-gang cases," Johnson v. Dye, ${ }^{36}$ came before the Third Circuit. Assuming that the power existed to make the inquiry, and without discussing prior authority in extradition cases, the court concluded that the petitioner "must be set at liberty for the State of Georgia has failed signally in its duty as one of the sovereign States of the United States to treat a convict with decency and humanity." 37 The petitioner had escaped to Pennsylvania from a Georgia prison where he was serving a long sentence for murder. Arrested and held for extradition, he sought by petition for habeas corpus, first in the Pennsylvania state courts and then in the federal district court, to prevent his return. He had not, however, appealed the denial of his petition beyond the intermediate appellate state court before going into the federal courts. The petitioner attacked his extradition on three grounds: (1) the unconstitutionality of the trial in which he was convicted in Georgia, (2) the subjection during imprisonment in Georgia to cruel and unusual punishment in violation of the Fourteenth Amendment, and (3) the likelihood of further subjection to cruel and unusual punishment should he be returned. The Third Circuit reversed the district court's denial of the petition, relying on the second ground: past deprivation of constitutional rights. To reach this conclusion it was necessary to decide: (1) that the extraditee need not exhaust his state remedies in the asylum state before entering the federal courts, ${ }^{38}(2)$ that the constitutional question raised by the petitioner was within the jurisdiction of

${ }^{34}$ There was almost no prior authority, the only case on the point being People ex rel. Whitfield v. Enright, 117 N.Y. Misc. 448, 191 N.Y. Supp. 491 (S. Ct., 1921)(court of asylum state could not consider upon habeas corpus the alleged unconstitutionality of grand jury selection). Consult Race Discrimination and Interstate Rendition-The Crawford Case, 43 Yale L. J. 444 (1934).

${ }^{35}$ Meanwhile the New Jersey courts passed on the question in a series of cases dealing with escaped prisoners, holding that the courts of the asylum state are without jurisdiction to consider alleged deprivation of the constitutional rights of the extraditee by the demanding state. Powell v. Meyer, 134 N.J.L. 169, 46 A. 2d 671 (S. Ct., 1946); In re Cotton, 24 N.J. Misc. 267, 47 A. 2d 830 (S. Ct., 1946); In re Colier, 140 N.J. Eq. 469, 55 A. 2d 29 (Err. \& App., 1947). Accord: Huff v. Ayers, 6 N.J. Super. 380, 71 A. 2d 392 (Super. Ct., 1950).

${ }^{28} 175$ F. 2d 250 (C.A. 3d, 1949).

${ }^{37}$ Ibid., at 256.

${ }^{38}$ Since the petitioner had not exhausted his state remedies in either Pennsylvania (the asylum state) or Georgia (the demanding state), this was necessary to the decision. There was authority to support this position, but a conflict existed. Compare United States ex rel. McCline v. Meyering, 75 F. 2d 716, 718 (C.A. 7th, 1934) with Powell v. Meyer, 147 F. 2d 606, 607 (C.A. 3d, 1945). 
the court on habeas corpus, and (3) that the petitioner had established that he had been denied his constitutional rights by the demanding state.

Only with difficulty can the decision be rationalized into the traditional scheme of habeas corpus. The argument is that the detention by the asylum state is illegal since it effectuates an unconstitutional act of the demanding state - a conviction or confinement in violation of the Fourteenth Amendment. ${ }^{39}$ This argument is tenuous at best, for cruel and unusual punishment in the de-manding state would seem to have little or no relation to the legality of the detention by the asylum state. Yet the Third Circuit, undoubtedly moved by the appealing claim presented by the fugitive, and not wishing to return him to the scene of abuses he had proven, relied on this past deprivation of constitutional rights in releasing him.

The Supreme Court reversed Johnson v. Dye in an unedifying per curiam decision on the ground, apparently, that state remedies had not been exhausted, but gave no hint as to which state they were referring to-the asylum state or the demanding state. ${ }^{40} \mathrm{~A}$ number of courts, assuming that the decision of the Third Circuit was good law except on the point that remedies of the asylum state need not be exhausted before entry into the federal courts, allowed escaped prisoners to introduce evidence concerning the constitutionality of their conviction and incarceration in the demanding state. 11

A forceful reassertion of the limited scope of inquiry on habeas corpus in extradition cases was the next development. In Johnson $v$. Matthewes ${ }^{42}$ an escaped convict held for rendition charged that he had been subjected to cruel and inhuman treatment in the demanding state. The Court of Appeals for the District of Columbia held that the established scope of habeas corpus in extradition cases did not permit inquiry into the constitutional question by courts located in the asylum state. The decision explicitly turned on the lack of jurisdiction in the federal court to hear the question on habeas corpus. ${ }^{43}$

The decision in Johnson v. Mathewes created a sharp conflict between circuits. Two years later, after the Eighth and Ninth Circuits had followed the Mattheres case, ${ }^{44}$ the Supreme Court was called upon to resolve the conflict in Sweeney v. Woodall. ${ }^{45}$ An escaped convict held for extradition charged both past and pros-

${ }^{39}$ See Horowitz \& Steinberg, The Fourteenth Amendment-Its Newly Recognized Impact on the "Scope" of Habeas Corpus in Extradition, 23 So. Cal. L. Rev. 441, 446 et seq. (1950).

${ }^{40}$ Dye v. Johnson, 338 U.S. 864 (1949). The cryptic opinion cited Ex parte Hawk, 321 U.S. 114 (1944) (state remedies must be exhausted before a conviction in a state court could be tested on habeas corpus in the federal courts).

41 Ex parte Marshall, 85 F. Supp. 771 (D. N.J., 1949); Harper v. Wall, 85 F. Supp. 783 (D. N.J., 1949); United States ex rel. Jackson v. Ruthazer, 181 F. 2d 588 (C.A. 2d, 1950); Application of Middlebrooks, 88 F. Supp. 943 (S.D. Cal., 1950).

42182 F. 2d 677 (App. D.C., 1950).

43 Thid., at 679.

44 Davis v. O'Connell, 185 F. 2d 513 (C.A. 8th, 1950); Ross v. Middlebrooks, 188 F. 2d 308 (C.A. 9th, 1951).

${ }^{45} 344$ U.S. 86 (1952). 
pective subjection to cruel and inhuman treatment by the demanding state. The Supreme Court held that the prisoner could not raise these questions in a federal court in the asylum state, at least without showing that remedies were unavailable in the demanding state. The language of the per curiam opinion places the decision on narrow grounds, keyed to the particular facts before the Court. The Court stated that the fugitive "has asked the federal court in his asylum to pass upon the constitutionality of his incarceration in the demanding state, although the demanding state is not a party before the federal court ${ }^{46}$ and although he has made no attempt to raise such a question in the demanding state. The question is whether, under these circumstances, the district court should entertain the fugitive's application on its merits."47 The Court's negative decision resolved the conflict, but the holding, if confined to the facts presented, leaves many questions unanswered.

A recent Illinois case, People ex rel. Gilbert v. Babb, ${ }^{48}$ raised what is perhaps a third type of question involving a constitutional claim on behalf of an extraditee. The question presented was whether the courts located in the asylum state could ever inquire into the constitutionality of the crime for which extradition is sought. Margaret Gilbert, the relator, had associated in Massachusetts during the period from 1947 to 1951 with persons of suspected Communist affiliation. Massachusetts authorities wanted her to testify concerning these associations, but Mrs. Gilbert had left Massachusetts to take up residence in Illinois. Efforts failing to obtain her voluntary attendance as a witness, Mrs. Gilbert was indicted by a Massachusetts grand jury for the common-law crime, in Massachusetts, of conspiracy to overthrow the government, ${ }^{49}$ and her extradition was demanded. Detained under an extradition warrant issued by the governor of Tllinois, Mrs. Gilbert contended, in a habeas corpus proceeding, that she was not substantially charged with a crime under the laws of the demanding state, first, because such crime could not exist in violation of the protection accorded free speech under the First Amendment, and second, because the Massachusetts indictment was unconstitutionally vague and indefinite. The Tllinois Supreme Court denied her appeal as to the first argument on the ground that the constitutionality of the crime alleged was not within the permissible scope of inquiry in habeas corpus proceedings in the asylum state, and as to the second on the

${ }^{18} \mathrm{Cf}$. Johnson v. Dye, 175 F. 2d 250, 253, 257-58 (C.A. 3d, 1949). There a concurring judge felt that the failure of the State of Georgia to appear was an indication of a lack of interest in Johnson which lent some substance to Johnson's arguments.

${ }^{47}$ Sweeney v. Woodall, 344 U.S. 86, 88-89 (1952).

48415 III. 349, 114 N.E. 2d 358 (1953).

19 The indictment charged that the relator "did conspire . . . to advocate, advise, counsel and cite the overthrow by force and violence of the government of the Commonwealth of Massachusetts by speech, exhibition, distribution and promulgation of certain written and printed documents, papers and pictorial representations, against the peace of said Commonwealth, and contrary to the form of the statute in such case made and provided." Ibid., at 359 and 364 . The reference to statute was admittedly surplusage: Mrs. Gilbert was charged with a common-law crime retained by Massachusetts. 
ground that the technical sufficiency of the indictment could not be questioned. The court felt that, although there was no case determining the exact point, prior authority recommended, if it did not require, the result reached. ${ }^{50}$

In Pearce v. Texas, ${ }^{51}$ a venerable Supreme Court case, a similar question was presented. Pearce had been indicted under an Alabama statute authorizing an indictment without allegations as to the time or place of the commission of the crime. He argued in rendition proceedings in the courts of the asylum state that this statute of the demanding state was unconstitutional, but they declined to consider the question and were upheld by the Supreme Court. The crucial question was not the technical sufficiency of the indictment as a criminal pleading but rather the substantive sufficiency of the charge of crime. In allowing the demanding state by statute to withdraw habeas corpus jurisdiction from the asylum state the case went much further, for it denied the fugitive any possibility of showing that he was not present in the demanding state at the time the crime was committed or that he is not substantially charged with a crime. The habeas corpus proceeding was reduced to an inquiry as to whether the fugitive was the person named and the papers were in proper order. The refusal to examine the constitutionality of the demanding state's law in the Gilbert cases is less startling.

The constitutional argument advanced by the fugitive in the Gilberl case bears a marked similarity to claims of past deprivation of constitutional rights such as were advanced in Hale v. Crawford, ${ }^{52}$ where it was claimed that the indictment was void since it had been returned by an improperly constituted grand jury. Mrs. Gilbert's theory was much the same: since the crime alleged against her was unconstitutional, the indictment returned under it and the requisition papers were void and there was no substantial charge of crime. This reasoning, however, would seem to be more tenuous than in the Crawford situation, since the indictment, though based on an unconstitutional crime or statute, meets the formal requirements and can hardly be said not to have existed.

The pressure to expand the scope of inquiry of habeas corpus in extradition cases, as manifested in the three types of cases discussed above, has on the whole produced meager results. Only in one case involving the prospective deprivation of constitutional rights has the inquiry been allowed and the extraditee released. ${ }^{53}$ Although the inquiry has been allowed in many cases dealing with past deprivation of constitutional rights, ${ }^{54}$ the decision of the Supreme Court in Sweeney v. Woodall ${ }^{5}$ forecloses that result in the future. No reported cases have

${ }^{60}$ Ibid., at 356 and 362.

51 155 U.S. 311, 313-14 (1894), aff'g 23 S.W. 15 (Tex. Cr., 1893).

${ }^{62} 65$ F. 2d 739 (C.A. 1st, 1933). See pages 740-741 supra.

${ }^{53}$ Commonwealth ex rel. Mattox v. Superintendent of Prison, $152 \mathrm{~Pa}$. Super. 167, $31 \mathrm{~A}$. 2d 576 (1943).

${ }^{54}$ See cases cited notes 36 and 41 supra.

ธ5 344 U.S. 86 (1952). 
allowed an inquiry by courts located in the asylum state into the constitutionality of the crime for which rendition is sought. Direct constitutional attack by the extraditee has undoubtedly been less fruitful than a number of other circuitous modes of attack. ${ }^{56}$

\section{III}

The writ of habeas corpus, in interstate rendition as wcll as in other areas, obviously "cannot be made the instrument for re-determining the merits of all cases in the legal system that have ended in detention." scope of inquiry on habeas corpus are therefore a necessity. In interstate rendition the limitations have been formulated in terms both of the exhaustion of state remedies and the jurisdictional power of the courts. It may be suggested that these formulations, often merged and confused by the courts, are conclusions expressing the result rather than determinative tests of the scope of the writ.

The "exhaustion of state remedies" formulation is the less helpful, for, strictly speaking, it is not directly relevant to the rendition situation. The concept of the exhaustion of state remedies arose out of the concurrent jurisdiction of state and federal courts to issue writs of habeas corpus to persons held under color of any law of the United States or in violation of the Constitution or laws or treaties of the United States. ${ }^{58}$ The doctrine of comity ${ }^{59}$ between federal and state courts gradually resolved the problem. Federal courts, acting under this principle, deferred action on petitions for habeas corpus until state courts with concurrent jurisdiction had passed on the matter, denying jurisdiction as a matter of judicial discretion. ${ }^{60}$ Discretion hardened into a mandatory rule that

56 As a matter of common practice, the governor of the asylum state exercises discretionary power whether or not to grant extradition warrants. Among the reasons for which extradition has been refused are the danger of lynching in the demanding state, a suspicion that the prosecution is motivated by bad faith or is spurious, and, perhaps, the denial-past or prospectiveof constitutional due process in the demanding state. Consult Note, $32 \mathrm{Col}$. L. Rev. 1411, 1419 n. 48 (1932). Moreover, the courts of the asylum state have occasionally released an extraditee on habeas corpus, disguising their action under any one of a number of technical holdings. Consult Habeas Corpus in Interstate Rendition, 47 Col. L. Rev. 470, 475 n. 51 (1847).

57 Hart \& Wechsler, op. cit. supra note 1, at 1239.

58 Broad authority to grant writs of habeas corpus "where any person may be restrained of his or her liberty in violation of the constitution, or of any treaty or law of the United States" was conferred upon the federal courts by 14 Stat. 385 (1867). Today, the jurisdiction of the federal courts to grant writs of habeas corpus can be found in 62 Stat. 964 (1948), 28 U.S.C.A. $\$ 2241$ (1949).

ss Comity arises from the mere fact that we have a dual system of government comprised of many state sovereignties and an overarching federal government. There are two types of comity: (1) between a state government and the federal government, and (2) between state governments. Exhaustion of state remedies properly applies only to the former. Inasmuch as interstate rendition involves the cooperation of states in the enforcement of their criminal law it is concerned with comity of the second type; but since it is a federal process supervised by the federal courts it encompasses both aspects of comity.

${ }^{60}$ Ex parte Royall, 117 U.S. 241 (1886); cf. Whitten v. Tomlinson, 160 U.S. 231 (1895). 
state remedies must be exhausted before resort to the federal courts. ${ }^{61}$ In 1948 this rule was codified. ${ }^{62}$

Exhaustion of state remedies has been most often involved where a person contests the constitutionality of his conviction by a state court. He may not do so in a federal court until all state remedies have been exhausted. In extradition cases, where two states are involved, this rule should properly be applied only to the asylum state where the extraditee challenges the legality of his detention. But the courts have often phrased their decisions declining to hear the constitutional question in the asylum state in terms of the necessity of exhausting the remedies of the demanding state before they could take jurisdiction. Although this is a way of deciding the permissible scope of inquiry on habeas corpus, it is confusing because of its inappropriate application to state courts (the rule properly refers only to a federal court deferring a habeas corpus proceeding until the remedies of the state in which the federal court sits have been exhausted) and to courts located in the demanding state (the rule contemplates only one state, whose remedies must be exhausted before the federal courts within that state may act). The courts, however, have persisted in the use of the "exhaustion of state remedies" terminology for perhaps two reasons: as a convenient though indelicate method of incorporating comity ideas, ${ }^{63}$ and as a method of reserving the possibility, in exceptional cases which might arise, of hearing the constitutional claim in the asylum state.

The jurisdictional power of courts located in the asylum state to consider constitutional questions raised by the fugitive would appear to be a sounder and more basic approach to the problem here involved. Yet, even though it states the problem in its ultimate terms, it provides no certain answer, because the concept of "jurisdiction" is shifting in meaning, abstract in character, and diffcult of application. An illustration may suffice: it can be argued, on the one hand, that the asylum state's detention of the fugitive is based on Article $I V$ of the Constitution and that when the requirements of that article are once met, there can be no further inquiry in the sense that a court would not have the power to proceed further. But, on the other hand, a fugitive challenging his detention and prospective extradition by way of a constitutional assertion of rights is not generally contradicting that he is held in accordance with Article IV. His assertion is rather that the action of the asylum state in holding him in custody is illegal since it effectuates an unconstitutional act of the demanding

61 Ex parte Hawk, 321 U.S. 114 (1944). For a discussion of this gradual development into a mandatory rule, see Hart \& Wechsler, op. cit. supra note 1, 1268-99 (1953).

0262 Stat. 967 (1948), 28 U.S.C.A. $\$ 2254$ (1950): "An application for a writ of habeas corpus in behalf of a person in custody pursuant to the judgment of a State court shall not be granted unless it appears that the applicant has exhausted the remedies available in the courts of the State, or.that there is either an absence of available State corrective process or the existence of circumstances rendering such process ineffective to protect the rights of the prisoner." Exhaustion of state remedies has been held to include certiorari to the Supreme Court. Darr v. Burford, 339 U.S. 200 (1950).

${ }^{83}$ See page 751 infra. 
state: a void indictment or trial, an inhuman confinement, the irreparable danger of future inhuman confinement or loss of life, or an unconstitutional crime. ${ }^{64}$ Here at once, one constitutional provision is brought face to face with another-their interaction and conflict is itself the source of the problem. "Jurisdiction," insofar as it is something other than precedent, is no guide.

Concepts such as "jurisdiction," "power," or "authority," distinctions between actions that are "void" and merely "voidable," while traditional and relevant in marking boundaries ..., serve less often to explain than to express conclusions as to whether relief on the writ shall lie. Other factors may have a more generative influence upon results, such as the nature and importance of the legal right asserted to establish illegality, the need for speed in the determination and the availability of other remedies, the extent to which the inquiry upon the writ will further or will thwart the ordinary processes of law administration, the impact of the inquiry on tender areas of power distribution like the relation between federal and state or civilian and military courts. ${ }^{65}$

The problem, easily and oversimply stated in terms of "jurisdiction" or "power," cannot be resolved without a discussion of fundamental policies.

The reasons usually advanced for hearing the constitutional claim of the extraditee in the courts of the asylum state stem from a desire to protect the rights of the individual. It is argued that comity-both interstate and statefederal-is a rule of convenience and not of necessity, and that the interstate rendition mechanism will not be crippled by allowing the fugitive to present his constitutional argument before his rendition rather than after. ${ }^{66}$ This reasoning is based, although usually not explicitly, on three closely related and far-reaching ideas. First, that as a practical matter remedies are unavailable to the fugitive in the demanding state, or, at the very least, are accessible only after much travail. It is true that the remedies of the demanding state may be beset with difficulties, ${ }^{67}$ but it is generally not the case that remedies are entirely unavailable. ${ }^{68}$ Difficulties of proof, the burden of persuading a jury, and other such factors are necessary concomitants of litigation itself and can hardly be abandoned by any tribunal.

A second idea is more basic. This is the belief that the fugitive will not re-

"Consult Horowitz \& Steinberg, op. cit. supra note 39 (passim).

${ }^{65}$ Hart \& Wechsler, op. cit. supra note 1, at 1239. Consult The Writ of Habeas Corpus in the Federal Courts, 35 Col. L. Rev. 404 (1935); The Freedom Writ-The Expanding Use of Federal Habeas Corpus, 61 Harv. L. Rev. 657 (1948).

${ }^{66}$ Consult Horowitz \& Steinberg, op. cit. supra note 39; Habeas Corpus in Extradition Proceedings, 1 Duke Bar J. 188 (1951); The Scope of Habeas Corpus Inquiry in Extradition Cases, $48 \mathrm{Nw}$. U. L. Rev. 634 (1953). Judicial expressions are to be found in Johnson v. Dye, 175 F. 2d 250 (C.A. 3d, 1949) (Judge Biggs); Johnson v. Matthews, 182 F. 2d 677, 684 (App. D.C., 1950) (Judge Bazelon, dissenting); Application of Middlebrooks, 88 F. Supp. 943 (S.D. Cal., 1950) (Judge Carter); and Sweeney v. Woodall, 344 U.S. 86, 91 (1952) (Justice Douglas, dissenting).

${ }^{67}$ Consult Prisoners' Remedies for Mistreatment, 59 Yale L. J. 800 (1950).

${ }^{88}$ In Georgia, the state involved in most of the "chain-gang cases," the state constitution provides that the writ of habeas corpus may not be suspended. Ga. Const. Art. 1, \&1, cl. 11 . It is supplemented by state statute. Ga. Code Ann. (1937) \& 50-101 et seq. 
ceive substantial justice in the demanding state. Remedies, it is argued, may be available in the sense that they appear on the statute-books; yet, as a matter of actual fact the existence of race or other prejudice rebuts the presumption that the political authorities and judicial system of the demanding state can be relied upon to give the fugitive a fair trial, correct constitutional abuses and secure him from violence. The abstract legal right is negatived by the prejudice or discrimination, the existence of which, it is thought, is capable of proof in the courts of the asylum state. Judge O'Connell, dissenting in part in Johnson v. Dye, gave explicit recognition to this: "In the absence . . . of effective steps toward reform in Georgia ... . it would be ingenuous to expect... Georgia authorities [whom the victim has accused of misconduct] to accord to Johnson's constitutional rights greater respect than this court finds was conceded to Johnson during his Georgia imprisonment." ${ }^{169}$ Although this belief is the very foundation for the view that the asylum state should concern itself with the constitutional questions raised by the fugitive, it has been explicitly recognized by only a few courts and commentators. ${ }^{70}$ Yet it is necessary to that view. If complete justice would be given the fugitive in the demanding state, the preservation of the fugitive's constitutional rights would not demand that courts located in the asylum state consider them.

Third, the idea that the best way to improve the protection accorded to constitutional rights is to have each state, as well as the federal court system, police the laws, procedures and institutions of other states. This is analagous to the reasoning supporting the exclusion by the federal courts of evidence obtained by means of an illegal search and seizure, the argument being that the only effective way to enforce proper police conduct is to take away the fruits of the illegally acquired evidence, even if this means the release of a guilty person. ${ }^{71}$ In the extradition situation a person charged with or convicted of crime would be released because of past or prospective denial of constitutional due process by the demanding state; in order to enforce its criminal law the demanding state would be required to give protection to the individual's constitutional rights. This is not without some effect: following the criticism of its penal system in the first chain-gang cases and attendant nation-wide publicity, Georgia abolished chain gangs by statute. ${ }^{72}$ But this argument does not have the same force in the

${ }^{69}$ Johnson v. Dye, 175 F. 2d 250, 258 (C.A. 3d, 1950).

70 Consult Sutherland, Due Process and Cruel Punishment, 64 Harv. L. Rev. 271 (1950), and see the dissent of Judge $O^{\prime}$ Connell in Johnson v. Dye, 175 F. 2d 250, 257-59 (C.A. 3d, 1949).

71 See Weeks v. United States, 232 U.S. 383 (1914) (in federal prosecution in federal court evidence obtained by means of an illegal search and seizure by federal officers not admissible against the accused). But cf. Woif v. Colorado, 338 U.S. 25 (1949), and Irvine v. California, 347 U.S. 128 (1954). See the dissent of Justice Douglas in Irvine v. California, ibid., at 149-52, for an expression of the policy involved when exclusion of evidence is used as a sanction in order to enforce lawful police conduct.

72 Georgia abolished chain gangs by statute in 1946. Whipping, shackles and stripes were explicitly forbidden. Ga. Code Ann. (Supp., 1951) § 77-370. 
extradition area as it does in the illegal-evidence situation, mainly because it is the citizens of the asylum state who bear the burden of the demanding state's constitutional lapses. The fugitive, usually accused or convicted of a sierious crime, will be released in their midst, ${ }^{73}$ and the grapevine will quickly carry back to the demanding state an invitation to those similarly situated. ${ }^{74}$

Although never attaining a determinative position, and usually going unvoiced, there is a substratum of emotional reaction which should be mentioned. A basic fact is that the fugitive often presents a very appealing claim. Moreover, the ancient idea of a place of refuge ${ }^{75}$ is a lurking symbol: there must be a sanctuary to which an individual can retreat, where there can be a fresh start in life with the past forgotten. A parallel can be drawn here to the strange but strong emotional appeal of the condemned man who resists on constitutional grounds a second subjection to the executioner, after the first attempt at execution has failed. ${ }^{76}$ This idea has no legal expression, but its emotive impact may help a court to a decision justified in legal terms.

The view that courts, state or federal, located in the asylum state should not inquire into the constitutional claim asserted by the fugitive has been triumphant in the courts. The underlying policies originate in the constitutional provision respecting extradition and appeal to the power of precedent (the traditionally narrow scope of habeas corpus in extradition cases), but rest ultimately on the paramount importance to our federalism of federal-state and interstate . comity.

The constitutional provision for interstate rendition creates by its phrasing a duty on a state to deliver up to the demanding state a person who has (1) been "charged" with a crime and (2) "fled" from justice. ${ }^{77}$ From this wording, sub-

${ }^{73}$ The only remedy available to the courts of the asylum state, apparently, is to release the fugitive on habeas corpus. In re Paramore, 95 N.J. Eq. 386, 387, 123 Atl. 246, 247 (Ch., 1924). It is doubtful whether a federal prisoner can be remanded to a federal prison with instructions for the protection of his constitutional rights. Cf. Coffin v. Reichard, 143 F. 2d 443 (C.A. 6th, 1944), and Williams v. Steele, 194 F. 2d 32, 34 (C.A. 8th, 1952). No injunctive relief would seem possible when a state prisoner is involved. Consult Prisoner's Remedies for Mistreatment, 59 Yale L. J. 800 (1950). The release of the fugitive on habeas corpus is an inconclusive remedy, for if the fugitive leaves the asylum state rendition proceedings may begin anew in the second state refuge. Consult Powell v. Meyer, 134 N.J.L. 169, 46 A. 2d 671 (S. Ct., 1946) and Habeas Corpus in Interstate Rendition, 47 Col. L. Rev. 470, 477 (1947).

74 While it is true, as pointed out by Horowitz \& Steinberg, op. cit. supra note 39 , at 457 , ? and in Scope of Habeas Corpus Inquiry, 48 Nw. U. L. Rev. 634, 638 (1953), that prisoners do not escape in order to resist their extradition from the state to which they escape, there are yet some grounds to fear such an occurrence in the future. And the Supreme Court's suggestion that an escaped prisoner should have no more rights because of his escape than he would have had had he remained in the demanding state has force. Sweeney v. Woodall, 344 U.S. 86,79 (1952).

${ }^{75}$ See Num. 35:9-15, 26-29 [Old Testament, AV].

${ }^{76}$ See Louisiana ex rel. Francis v. Resweber, 329 U.S. 459 (1947) (subjection to a second electrocution, after first attempt had failed, not cruel and unusual punishment).

${ }^{77}$ See notes 4 and 5 supra. 
stantially repeated in the federal statute enforcing the constitutional provision, have arisen the four discrete questions which courts in the asylum state, whether they be state or federal, have traditionally considered on habeas corpus. Consequently, rendition has been viewed as a step toward the prosecution of accused persons, which is largely procedural in nature. It is often said that no substantive rights are involved in the habeas corpus hearing, ${ }^{78}$ and that it is a summary process designed to correct obvious mistakes, and testing only the legality of - detention by the asylum state. ${ }^{79}$

A cluster of ideas grouped around the word "comity" is the primary foundation for the view that courts located in the asylum state should refuse to inquire into the constitutional question raised by the fugitive. Comity, both between the states themselves and between the state and federal governments, is a crucial consideration. ${ }^{80} \mathrm{~A}$ court located in one state should defer action on causes properly within its jurisdiction "until the courts of another sovereignty with concurrent powers, and already cognizant of the litigation, have had an opportunity to pass on the matter." "[I] t would be unseemly in our dual system of government for a federal district court to upset a state court conviction without an opportunity to the state courts to correct a constitutional violation. . . ."82

A number of factors are involved here: the idea that courts in one state should not pass on the laws or institutions of another state; ${ }^{83}$ the general reluctance of courts to consider at an early stage a constitutional question that might well become academic (if, for example, the person extradited should be discharged or acquitted in the demanding state) ${ }^{84}$ the fact that courts in the asylum state are far removed from the scene of the alleged constitutional violation, with consequent difficulty in determining any factual or even legal questions involved and forcing the demanding state to defend the constitutionality of its laws or institutions in a distant forum; 85 and the dangers, if courts in the asylum state were permitted as a matter of course to hear the constitutional

${ }^{78}$ See Illinois ex rel. McNichols v. Pease, 207 U.S. 100, 112 (1907); Johnson v. Matthews, 182 F. 2d 677, 682 (App. D.C., 1950).

${ }^{79}$ See Drew v. Thaw, 235 U.S. 432, 439-40 (1914).

${ }^{80}$ See Appleyard v. Massachusetts, 203 U.S. 222, 227-28 (1906); Pierce v. Creecy, 210 U.S. 387, 404 (1908); Johnson v. Matthews, 182 F. 2d 677, 679-82 (App. D.C., 1950).

81 Darr v. Burford, 339 U.S. 200, 204 (1950). See Ross v. Middlebrooks, 188 F. 2d 308, 311 (C.A. 9th, 1951).

82 Darr v. Burford, 339 U.S. 200, 204 (1950).

${ }^{83}$ All state courts are equally bound to observe the Constitution as the supreme law of the land. Robb v. Connolly, 111 U.S. 624 (1884). Yet the propriety of one state court's doing so under the assumption that the courts of another state will not do so, when such an assumption means passing judgment on the laws or institutions of a sister state, is open to serious question.

${ }^{84}$ See Albertson v. Millard, 345 U.S. 242 (1953), for a recent Supreme Court expression of this policy.

${ }^{85}$ In Sweeney v. Woodall, 344 U.S. 86, 90 (1952), the Supreme Court stated that the demanding state should not be put under the obligation of defending its laws or institutions in a distant forum in order to enforce its criminal law. But see note 46 supra. 
questions, both to the efficient operation of the rendition process and to interstate harmony. Criticism of the institutions of one state by federal or state courts located in another state creates strong resentment, ${ }^{86}$ and the ability on the part of a fugitive to resist extradition through successive applications for habeas corpus in both the state and federal courts of the asylum state, by raising constitutional questions, could delay extradition and consequent prosecution for a long period. ${ }^{87}$ At any rate, no matter how these conflicting policies are balanced, there is no doubt that the Supreme Court takes comity very seriously: "Considerations fundamental to our federal system require that the prisoner test the claimed unconstitutionality of his treatment by Alabama in the courts of that state." 88

Although the rule seems clearly established that the constitutional question of the fugitive's mistreatment by the demanding state should be left to the courts of that state, a possible exception remains. The Supreme Court in Sweeney v. Woodall used the language of the "exhaustion of state remedies" cases. ${ }^{89}$ Applied to the extradition situation, the idea that remedies must be exhausted in the demanding state before courts of the asylum state can hear the question precludes all inquiry into the constitutional question in the asylum state, except in the situation where it is shown that no remedies are available in the demanding state..$^{90}$ This possible exception, not yet passed upon by the courts, would not include cases of past deprivation of constitutional due process.

The least deserving situation for relief in the asylum state would appear to be where it is claimed, as in the Gilbert case, that the alleged crime is itself unconstitutional, for there there is no threat of physical violence and a remedy would always be available in the demanding state for such a claim. The personal inconvenience to the fugitive should not be allowed to defeat the efficient operation of the rendition process. But in the rare situation in which the fugitive is able to establish a grave danger of lynching or mob violence, it can still be argued that a court in the asylum state should make the inquiry, putting the fugitive to his

${ }^{86}$ For an example of the type of indignation aroused by the release of a fugitive on the grounds that justice would not be accorded him in the demanding state, see Race Discrimination and Interstate Rendition-The Crawford Case, 43 Yale L. J. 444, 445 (1934).

${ }^{87}$ As much as three or four years may be consumed by dilatory tactics. See Successive Applications for Habeas Corpus in State and Federal Courts in Interstate Rendition, 45 Yale L. J. 543 (1936).

${ }^{88}$ Sweeney v. Woodall, 344 U.S. 86,90 (1952).

${ }^{82}$ Ibid., at 89-90.

90 "Respondent makes no showing that relief is unavailable to him in the courts of Alabama. Had he never eluded the custody of his former jailers he certainly would be entitled to no privilege permitting him to attack Alabama's penal process by an action brought outside the territorial confines of Alabama in a forum where there would be no one to appear and answer for that State. Indeed, as a prisoner of Alabama, under the provisions of . . 28 U.S.C.A. $\$ 2254$, and under the doctrine of Ex parte Hawk . . . he would have been required to exhaust all available remedies in the state courts before making any application to the federal courts sitting in Alabama." Tbid., at 89. 
proof.91 For in this rare situation the petitioner has no other remedy-if he is lynched or subjected to cruelty there can be no repair. In such a case, proof of past deprivation of constitutional due process by the demanding state, though not sufficient by itself, may be relevant to show the possibility of prospective deprivation of constitutional rights for which no remedy is available.

In the vast majority of cases, however, such an argument should not be possible. State boundaries present no obstacle to a fleeing criminal. The extradition process, essential even in the earliest days of our nation, plays an even more vital role today in the interstate control of crime and the furtherance of criminal justice. The fugitive should not be allowed to delay and disrupt this process as a matter of course by raising constitutional questions involving past or prospective treatment by the demanding state. Assuming that a remedy is available in the federal courts of the demanding state and, as must be assumed, that federal courts throughout the breadth of the land will be vigilant in protecting the liberties of the fugitive, the inconvenience he suffers in being returned is overbalanced by the necessities of law enforcement and the requirements of an integrated federal system. These demand interstate rendition machinery of effciency and speed. The review upon habeas corpus of the detention of the fugitive by the asylum state must remain as a safeguard to the innocent, primarily for the correction of obvious mistakes; but the fundamental rights of the fugitive, except when remedies are entirely unavailable there, should be left to courts located in the demanding state.

\section{AGENTS' REPORTS AND THE ATTORNEY- CLIENT PRIVILEGE}

A problem which has led to divergent and confusing decisions arises from the assertion of the attorney-client privilege to prevent disclosure of reports prepared by corporate agents and eventually transmitted to counsel. In applying the privilege in these situations the courts have usually relied upon tests poorly adapted to correct analysis in terms of the basic rationale of the privilege.

This rationale assumes that full disclosure by the client ${ }^{1}$ to the attor-

91 Perhaps a distinction could be drawn between federal and state courts, allowing the federal court to inquire in to the constitutional question only in the exceptional situation noted and the state court not at all. This would prevent the unwholesome situation of one state's criticizing and declaring invalid the laws or institutions of a sister state. This practical differentiation between federal and state courts is contradicted by the fact that both have concurrent jurisdiction over habeas corpus in extradition cases. State courts, however, should be more reluctant, even in the most extreme situations, to inquire into the constitutional question. Federal courts, on the other hand, have as one of their primary tasks the reviewing of the constitutionality of state laws and even state institutions, when they are called into question. Federal supervision of state schools, Sweatt v. Painter, 339 U.S. 629 (1950), and state elections, Smith v. Allwright, 321 U.S. 649 (1944), is an established and relevant fact.

1 The problems inherent in applying the attorney-client rationale to statements from the attorney to the client are beyond the scope of this comment. The basis for such protection is 